\title{
CLINICOPATHOLOGICAL PATTERN OF TESTICULAR TUMORS A 3-YEARS EXPERIENCE AT A TERTIARY CARE UROLOGY CENTER
}

\author{
Badar Murtaza, Muhammad Rafiq Zafar, Zahoor Iqbal Mirza, Muhammad Akmal*, Hussain Ahmad, Muhammad Tanveer Sajid, \\ Hafeez Ud Din**
}

Armed Forces Institute of Urology/National University of Medical Sciences (NUMS) Rawalpindi Pakistan, ${ }^{*}$ Combined Military Hospital Lahore National University of Medical Sciences (NUMS) Pakistan, **Armed Forces Institute of Pathology/National University of Medical Sciences (NUMS) Rawalpindi Pakistan

\section{ABSTRACT}

Objective: To evaluate the clinical presentation of testicular tumors and their histological pattern present in our setup.

Study Design: Case series.

Place and Duration of Study: Armed Forces Institute of Urology (AFIU) Rawalpindi, from Jul 2016 to Jun 2019.

Methodology: The documents of all the cases of testicular tumors presenting in the last 3 years were retrieved and their relevant clinical detail: age, clinical presentation, side of involvement, operative procedure conducted and the histopathology report were documented.

Results: Thirty two patients of testicular tumors were documented over a period of three years, making 10.66 cases reporting per year. The mean age was $30.10 \pm 15.42$ years, with the youngest 3 months old infant and the eldest being 58 years of age. The tumors were commonest on the right $(59.3 \%)$ with $81.2 \%$ presentation as swelling of testis. Radical orchiectomy was performed in $90.6 \%$ of the cases and retro peritoneal lymph node dissection (RPLND) in $6.2 \%$. Germ cell tumors were found in $71.8 \%$ cases with mixed germ cell tumorbeing the commonest histopathology seen in $31.2 \%$ of the cases followed by the seminoma (25\%) and non-Hodgkin lymphoma (12.5\%).

Conclusion: Testicular tumors were relatively uncommon in our part of the world with a limited number of cases presenting to a tertiary care urology center. The presentation was variable but a rising trend in non-Hodgkin lymphoma results in a decrease in the overall number of germ cell tumors.

Keywords: Germ cell tumor, Radical orchiectomy, Seminoma, Undescended testis.

This is an Open Access article distributed under the terms of the Creative Commons Attribution License (http://creativecommons.org/licenses/by/4.0), which permits unrestricted use, distribution, and reproduction in any medium, provided the original work is properly cited.

\section{INTRODUCTION}

In developed countries, testicular tumour is the most commonly diagnosed cancer in males aged 15-44 year ${ }^{1}$. According to the American Cancer Society, the cancer statistics of 2016 reported that approximately 8720 new cases of testicular tumor were diagnosed in 2016, but only estimated 380 individuals would die of $\mathrm{it}^{2}$. Testicular tumors constitute around $1-1.5 \%$ of the male neoplasms ${ }^{3}$. As far as the urological tumors are concerned, testicular tumors represent $5 \%$ of the above. According to Vechhia $e^{2} \mathrm{al}^{4}$, in the western countries, 310 new cases of testicular tumors/100000 males/year, are being reported. The rising trend in testicular tumors has not been seen in the Asian countries, whereas the increasing incidence of these tumors have been recorded in the US and Europe ${ }^{5}$, especially in the Caucasian and Hispanic men in United States. Interestingly Ghazarian et $\mathrm{al}^{6}$, has even projected a rising incidence in the next decade in United States. Despite of the rising trend in testicular tumors, the mortality has decreased due to advances in the treatment modalities. Indeed early and accurate diagnosis is important for

Correspondence: Dr Badar Murtaza, Classified Urologist, Armed Forces Institute of Urology, Rawalpindi Pakistan

Received: 22 Nov 2019; revised received: 24 Dec 2019; accepted: 10 Jan 2020 successful management of testicular tumors as a delay in diagnosis relates with higher and advanced stage at the time of presentation for management.

A lot of research has been reported from the west about the testicular tumors, however the publications from Asian countries have been scarce. The main aim of this study was to highlight the mode of presentations of testicular tumors in our setup alongwith the operative procedures, the histological pattern and compare it with other national and international studies with the intention to specify the peculiar issues and patterns encountered in our circumstances.

\section{METHODOLOGY}

This retrospective case series study was conducted at the Department of Urology, at the Armed Forces Institute of Urology (AFIU) Rawalpindi, from July 2016 to June 2019. Due approval was acquired from the Institutional Ethics Review Board (Ref no: Uro-AdmTrg-1/IRB/2016/106). All the 32 patients presenting to the Armed Forces Institute of Urology, Rawalpindi with testicular tumor were included in this study by non-probability convenience sampling with no specific exclusion criteria. Their documents were retrieved and critically analyzed regarding the age, mode of presentation (including signs and symptoms), tumor markers 
( $\beta$-HCG, $\mathrm{a}-\mathrm{FP}, \mathrm{LDH})$ and operative procedures, while the histopathology reports were procured from the documents as well as from the Armed Forces Institute of Pathology (AFIP) Rawalpindi. The descriptive quantitative data analysis was conducted using the SPSS-21. The frequencies, percent-ages and the mean with standard deviations were calculated.

\section{RESULTS}

A total of 32 cases of testicular tumors were recorded during this period. This constituted 10.66 cases documented per year at our setup. The age ranged from 3 months to 58 years (mean $30.10 \pm 15.42$ years). Testicular tumors were found mostly in the third and fourth decade of life, constituting 18 cases $(56.25 \%)$ in these two decades. This was followed by the sixth decade which showed $15.6 \%$ of the patients. The tumors were more common on the right side (19 cases 59.3\%) with 10 cases on the left $(31.25 \%)$ and $3(9.3 \%)$ bilateral (fig-1).
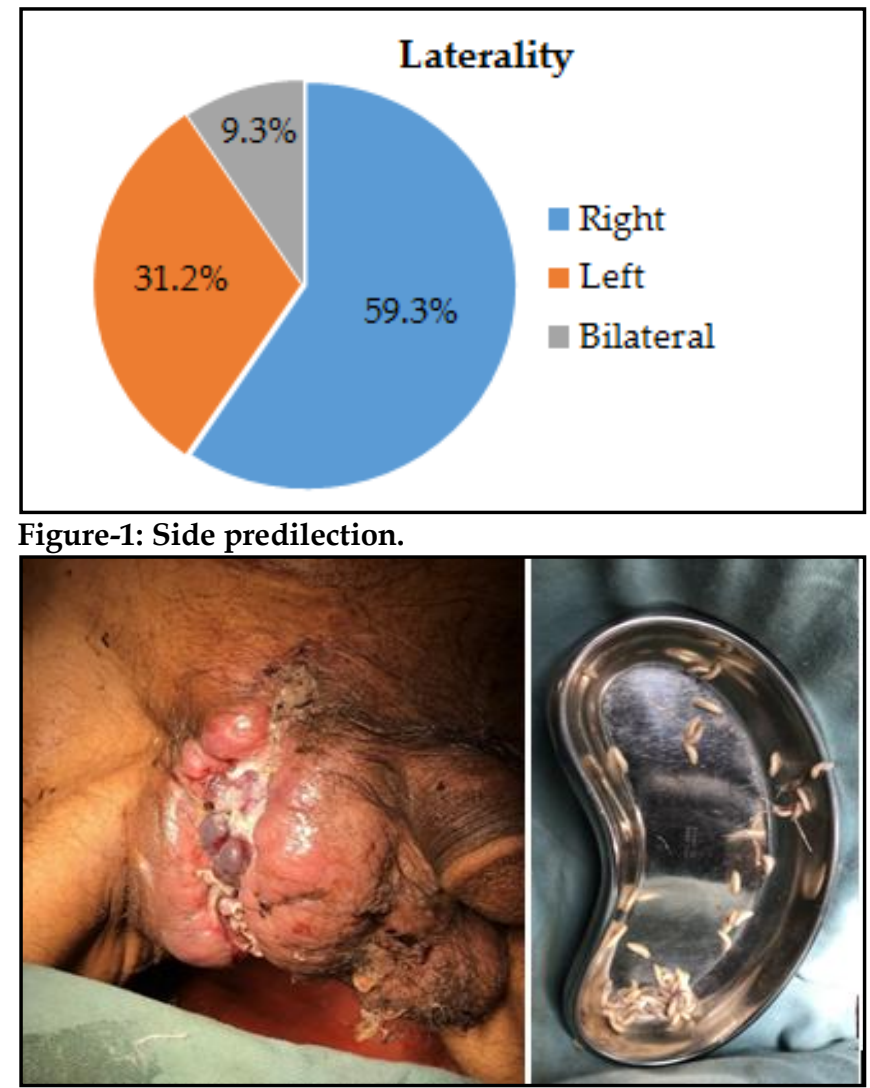

Figure-2: Ulcerating testicular tumor with maggots.

The commonest clinical presentation was swelling of testis found in 26 cases $(81.2 \%)$ of the patients. This was followed by dragging pain in 17 (53.1\%) (table-I). Two $(6.2 \%)$ cases presented with bilateral testicular swellings, while the third case of bilateral lesions infact had bilateral tumors in intraabdominal testes. Two $(6.2 \%)$ had abdominal mass at presentation along with cryptorchidism. One patient $(3.1 \%)$ had a past history of radical orchiectomy and was lost to follow up. He presented with a fungating/ulcerating inguino-scrotal lesion along with maggots (fig-2).

As far as the tumor markers are concerned, amongst the seminomas (8 cases), 1 (12.5\%) showed a raised $\beta$-HCG level. However in non seminomatous germ cell tumors (15 cases), a FP was raised in 9 cases $(60 \%)$ and $\beta$ HCG in 8 cases $(53.3 \%)$ of patients. Amid the total testicular tumors (32 cases), LDH was raised in only 5 cases $(15.6 \%)$.

Among the 32 patients, radical orchiectomy was performed in 29 (90.6\%). Two (6.2\%) cases had cryptorchidism who developed the tumors in the intraabdominal testes with one having bilateral intra-abdominal testes with tumors in both the testes. Due to obstructive uropathy secondary to abdominal lymphadenopathy, one of these required ureteric stenting prior to the diagnosis. In one patient $(3.1 \%)$ who presented with an inguinoscrotal ulcerating lesion, he was subjected to incisional biopsy of the lesion. Retro peritoneal lymph node dissection (RPLND) was performed in 2 cases $(6.2 \%)$.

Table-I: Clinical presentation of the patients $(n=32)$.

\begin{tabular}{l|c}
\hline Presentation & $\mathbf{n ~ ( \% )}$ \\
\hline Swelling of testis & $26(81.2)$ \\
\hline Dragging Pain in testis & $17(53.1)$ \\
\hline Severe Pain in testis & $3(9.3)$ \\
\hline Bilateral testicular swelling & $2(6.2)$ \\
\hline Hydrocele & $4(12.5)$ \\
\hline Cryptorchidism & $2(6.2)$ \\
\hline Abdominal Mass & $2(6.2)$ \\
\hline Weight Loss & $3(9.3)$ \\
\hline Inguino-scrotal Ulcer with Maggots & $1(3.1)$ \\
\hline Family History & $1(3.1)$ \\
\hline
\end{tabular}

Germ cell tumors were commonest among the lesions, seen in 23 cases $(71.8 \%)$. In detail it was the mixed germ cell tumor which was seen in 10 cases $(31.2 \%)$, followed by seminomas in 8 cases $(25 \%)$ and then diffuse large B cell lymphoma in 4 (12.5\%). A variety of other lesions were also seen. Interestingly one 6 years old boy was referred by the paediatrichaem-oncologist for radical orchiectomy in a known case of acute lymphoblastic leukemia (ALL) who had already undergone bone marrow transplant and developed a relapse in the testis (table-II). 
Table-II: Histopathological diagnoses.

\begin{tabular}{l|c}
\hline Histopathological Pattern & $\mathbf{n ~ ( \% )}$ \\
\hline Germ Cell Tumors (GCTs) & $23(71.8)$ \\
\hline Seminomatous GCTs & $8(25)$ \\
\hline Non-seminomatous GCTs & $15(46.8)$ \\
\hline Embryonal Carcinoma & $1(3.1)$ \\
\hline Yolk Sac Tumor & $3(9.3)$ \\
\hline Malignant Teratoma & $1(3.1)$ \\
\hline Mixed GCT & $10(31.2)$ \\
\hline Stromal/ Non-specific stromal Tumors & $9(28.1)$ \\
\hline Leydig cell Tumor & $3(9.3)$ \\
\hline Lymphoma & $4(12.5)$ \\
\hline ALL & $1(3.1)$ \\
\hline Angiomyxoma & $1(3.1)$ \\
\hline
\end{tabular}

\section{DISCUSSION}

The majority $(90-95 \%)$ of the testicular tumors constitute germ cell tumors $(\mathrm{GCT})^{4}$. Their etiology is not exactly known but the old hypothesis persists that the tumor process starts in the fetal life with involvement of abnormal proliferation of primordial germ cell. Testicular tumors are associated with certain risk factors like cryptorchidism, family history (first degree relative with testicular tumors), infertility, Klinefelter's syndrome and even trauma and hormonal changes. Cryptorchidism has 5-10 fold increased risk of evolving a testicular tumor. Likewise around $11 \%$ of these tumors are associated with cryptorchidism ${ }^{4}$, with seminoma being the commonest. In cases of cryptorchidism, the contralateral testis can also develop a testicular tumor. In our study we had only $6.2 \%$ association with cryptorchidism and both the cases developed testicular tumor in the intra-abdominal testes. Interestinglythe white collar workers have been found to be at higher risk of germ cell tumors as compared to the blue collar workers. Thus associationwith higher socioeconomic status cannot be ignored.

Amongst the testicular tumors, the non-seminomas have a peak incidence in 3rd decade while seminomas peak in 4 th decade of life. In our study we reported a combined $56.25 \%$ tumors in the third and fourth decade of life. Testicular tumors are a shade common on the right side which reflects the increased incidence of undescended testis on the right. Beigh et $a l^{7}$, reported $70.3 \%$ right sided tumors and Deotra et $a l^{8}, 60 \%$ as compared to $59.3 \%$ on right in our study. Bilateral tumors are seen in 1-2\% with about half associated with undescended testis. However we had 9.3\% bilateral tumors with one out of three having cryptorchidism.

In 1987, Jafarcy and Zaidi ${ }^{9}$, reported testicular tumors as $3.8 \%$ of all malignancies in Pakistan. While in 2007 Mushtaq et al ${ }^{10}$, reported an incidence of $1.24 \%$ testicular tumors of all male malignancies. The germ cell tumors are considered as the commonest variant of around $90-95 \%$ preponderance 4 . However Mushtaq et $a l^{10}$, reported $67.3 \%$ germ cell tumors (seminoma: nonseminoma ratio of 11:14) and interestingly lymphoma as the second commonest $18.7 \%$ amongst the patients of Northern Pakistan. They also found no increasing pattern of testicular tumors in Pakistan as compared to the tumor registry of $1991^{11}$. Similar to Mushtaq et al ${ }^{10}$, Chakrabarti et $a l^{12}$, from Central India reported germ cell tumor $(77.1 \%)$ as the commonest tumor followed by lymphoma $(17.1 \%)$. In two other studies from Pakistan the incidence of germ cell tumors has been found to be $87 \%^{13}$, and $>90 \%{ }^{14}$. However in our study we had $71.8 \%$ germ cell tumors as the commonest testicular tumor. In all the children we documented the presence of yolk sac tumor except one who was a known case of acute lymphoblastic leukemia treated with bone marrow transplant but developed a relapse in one of his testes. We found lymphoma in $12.5 \%$ cases, as the second most common tumor after germ cell tumors and all were diffuse large $B$ cell variant which has a relatively poorer prognosis. Testicular lymphoma is a rare disease comprising approximately $1-2 \%$ of all non-Hodgkin Lymphoma and about 5\% of testicular tumors, and is primarily a disease of the elderly. Apart from lymphomas, amongst the stromal tumors, Leydig cell tumors were seen in $9.3 \%$ of the cases in our study. These tumors may have endocrine abnormalities like loss of libido and gynaecomastia ${ }^{15}$, which were not seen in our patients. Earlier these were considered as rare tumors, however in the recent studies they have been reported as high as $3-22 \%$ of the testicular tumors ${ }^{16,17}$.

The testicular tumors are quite uncommon in underdeveloped areas like Pakistan, India and African countries as compared to the industrialized countries with higher socioeconomic status. An enormous difference can be appreciated from the fact that the maximum documented cases reporting in a year was seen in United Kingdom by Horwich et al ${ }^{18}$, which was 64.9 per year followed by Walschaerts et al ${ }^{19}$, from France with 53.2 per year, as compared to 1.5 from Nigeria ${ }^{20}$, and 7.4 from India7. In our study we documented 10.66 cases reporting in a year while in another study from Pakistan Mushtaq et $a l^{10}$, reported 21.4 cases in a year.

A painless swelling of one testis is the commonest presentation of testicular tumors ${ }^{13}$, reported $67.5 \%$ by Beigh et $a l^{7}, 100 \%$ by Tan $e t a^{21}$, as compared to $81.2 \%$ 
in our study. Indeed testicular self-examination, which is to be performed in men $>15$ years of age once a month after warm bath, can be helpful in early detection of these painless testicular swellings ${ }^{22}$. Other symptoms/signs encountered may be a dull dragging pain, pain with epididymo-orchitis, hydrocele, cryptorchidism, abdominal mass, scrotal ulceration and even infertility. We reported a case extensive inguino-scrotal ulcer alongwith maggots. He was infact a case who had lost to follow up after undergoing radical orchiectomy and presented after three years with this complication.

Raised tumor markers are not only diagnostically important but also play a prognostic role. Their importance in the follow up of these patients cannot be underestimated. a-fetoprotein (AFP) is produced in the fetus in yolk sac (endodermal sinus), intestine and liver. AFP is raised in yolk sac tumor, its increased level correlates with the amount of yolk sac tumor present in the mixed germ cell tumor and to a lesser extent by embryonal carcinomas and teratomas. It can be found in up to $20-25 \%$ of teratomas and is associated with mucinous glands and hepatoid differentiation. In one large cohort study of Germa-Lluch et al23, of 1490 cases of testicular tumor, $>60 \%$ of patients with non seminomatous germ cell tumors had raised AFP levels, making it the most commonly elevated tumor marker in testicular cancer. This figure was similar to our study where $60 \%$ cases of non seminomatous germ cell tumors showed elevated $\alpha$-fetoprotein.

On the other hand $\beta$-human chorionic gonadotrophin is raised in choriocarcinoma and at times in seminoma and mixed germ cell tumor with syncytiotrophoblastic cells. The extent of its rise depends on histologic tumor type and the overall tumor burden. Elevations of $\beta$-hCG can also be seen in approximately $10-20 \%$ of patients with stage I seminoma and up to $30-50 \%$ of disseminated seminoma secondary to the existence of syncytiotrophoblastic components within the tumor. In our study, $12.5 \%$ seminomas showed an elevated $\beta$ hCG as compared to $53.3 \%$ in non seminomatous germ cell tumors. Beigh et $a l^{7}$, showed elevated AFP and $\beta$ hCG levels in $8.1 \%$ and $43.24 \%$ respectively.

Serum lactic dehydrogenase (LDH) may be higher in seminomas and non-seminomas. It has relatively low specificity for germ cell tumors. LDH is elevated in $40-60 \%$ of men with testicular germ cell tumors. LDH has limited sensitivity and specificity for seminoma, but LDH levels >2000 U/L are more reliable with bulky disease, and increasing levels are a precise pointer towards recurrence. In our study serum LDH was found to be raised in $15.6 \%$ of the cases. An increased serum LDH level may be the singular biochemical aberration in $10 \%$ of patients with persistent or recurrent non seminomatous germ cell tumors. Rarely hormone producing tumors may cause hyperthyroidism, hypercalcaemia and even precocious pseudopuberty.

Radical orchiectomy was the main operative procedure $(90.6 \%)$ performed in our study. We had two cases of testicular tumor in the intra-abdominal testes. After initial diagnosis with trucut biopsy, these were managed by chemotherapy followed by exploration, excision of abdominal lesions along with the RPLND for the residual lymph node masses. We had no case of testis sparing surgery. However recent studies are supporting the concept of surgical exploration and frozen section assessment in indeterminate small testicular tumors and testis sparing surgery in order to avoid radical orchiectomy in certain patients ${ }^{24,25}$.

\section{CONCLUSION}

The presentation was variable but the association of cryptorchidism with testicular tumors was also quite evident. The latter group indeed requiring major interventions like retro peritoneal lymph node dissection. The incidence of testicular tumors in our Asian population is low as reflected by the number of cases reporting to a tertiary care urology center in Pakistan. In addition the number of non-Hodgkin lymphoma seen in the testis was also high thus reducing the overall incidence of germ cell tumors as compared to the rest.

\section{CONFLICT OF INTEREST}

This study has no conflict of interest to be declared by any author.

\section{REFERENCES}

1. Trabert B, Chen J, Devesa SS, Bray F, Mc Glynn KA. International patterns and trends in testicular cancer incidence, overall and by histologic subtype, 1973-2007. Androl 2015; 3(1): 4-12.

2. Siegel RL, Miller KD, Jemal A. Cancer statistics, CA Cancer J Clin 2016; 66(1): 7-30.

3. Nitta S, Sakka S, Endo T, Komine M, Sakata A, Tsutsumi M, et al. Metachronous bilateral testicular tumors with frequently recurrent hydrocele: a case report. Hinyokika Kiyo 2017; 63(3): 115-18.

4. La Vecchia C, Bosetti C, Lucchini F, Negri E, Boyle P, Levi F. Cancer mortality in Europe, 2000-2004, and an overview of trends since 1975 Ann Oncol 2010; 21(6): 1323-60.

5. Nigam M, Aschebrook-Kilfoy B, Shikanov S, Eggener S. Increasing incidence of testicular cancer in the United States and Europe between 1992 and 2009. World J Urol 2015; 33(5): 623-31.

6. Ghazarian AA, Kelly SP, Altekruse SF, Rosenberg PS, McGlynn KA. Future of testicular germ cell tumor incidence in the United States: Forecast through 2026. Cancer 2017; 123(12): 2320-28. 
7. Beigh A, Junaid S, Beg A, Farooq S, Wani LA, Manzoor F. Clinicopathological study of testicular tumors: an experience in a tertiary care hospital in Kashmir valley, Jammu and Kashmir, India. Int J Res Med Sci 2017; 5(6): 2741-46.

8. Deotra A, Mathur DR, Vyas MC. A 18 years study of testicular tumours in Jodhpur, western Rajasthan. J Postgrad Med 1994; 40(2): $68-70$

9. Jafarey NA. Zaidi SHM. Cancer in Pakistan. J Pak Med Assoc 1987; 37(1): 1-3.

10. Mushtaq S, Jamal S, Mamoon N, Akbar N, Khadim T. the pathological spectrum of malignant testicular tumours in Northern Pakistan. J Pak Med Assoc 2007; 57(10): 499-501.

11. Ahmad M, Khan AH. The pattern of malignant tumours in Northern Pakistan. J Pak Med Assoc 1991; 41(11): 270-73.

12. Chakrabarti PR, Dosi S, Varma A, Kiyawat P, Khare G, Matreja S. Histopathological trends of testicular neoplasm: An experience over a decade in a Tertiary care centre in the Malwa Belt of Central India. J Clin and Diag Res 2016; 10(6): EC16-18.

13. Gill MS, Shah SH, Soomro IN, Kayani N, Hassan SH. Morphological pattern of testicular tumors. J Pak Med Assoc 2000; 50(4): 110-13.

14. Talpur AH, Memon AS, Memon JM, Memon R, Memon MA. Testicular tumours. J LiaquatUni Med Health Sci 2003; 2(1): 7-11.

15. Muheilan MM, Shomaf M, Tarawneh E, Murshidi MM, AlSayyed MR, Murshidi MM. Leydig cell tumor in grey zone: a case report. Int J Surg Case Rep 2017; 35(1): 12-16.

16. Lagabrielle S, Durand X, Droupy S, Izard V, Marcelli F, Huyghe E, et al. Testicular tumours discovered during infertility workup are predominantly benign and could initially be managed by sparing surgery. J Surg Oncol 2018; 118(4): 630-35.

17. Pozza C, Pofi R, Tenuta M, Tarsitano MG, Sbardella E, Fattorini
G, et al. Clinical presentation, management and follow-up of 83 patients with Leydig cell tumors of the testis: a prospective casecohort study. Hum Reprod 2019; 34(8); 1389-403.

18. Horwich A, Nicol D, Huddart R. Testicular germ cell tumours. BMJ 2013; 347(1): f5526-28.

19. Walschaerts M, Huyghe E, Muller A, Bachaud JM, Bujan L, Thonneau P. Doubling of testicular cancer incidence rate over the last 20 years in southern France. Cancer Causes Controls 2008; 19(2): 155-61.

20. Salako AA, Onakpoya UU, Osasan SA, Omoniyi-Esan GO. Testicular and paratesticulartumours in south western Nigeria. Afr Health Sci 2010; 10(1): 14-17.

21. Tan GH, Arzif M, Shamsul AS, Ho CC, Praveen S, Goh EH. Clinico pathological features and survival of testicular tumours in a Southeast Asian university hospital: a ten-year review. Asian Pac J Cancer Prev 2011; 12(10): 2727-30.

22. Gutema H, Debela Y, Walle B, Reba K, Wondiye H. Testicular self-examination among Bahir Dar University students: application of integrated behavioral model. BMC Cancer 2018; 18(1): 21-25.

23. Germa-Lluch JR, Garcia del Muro X, Maroto P, Paz-Ares L, Arranz JA, Guma J, et al. Clinical pattern and therapeutic results achieved in 1490 patients with germ cell tumours of the testis: the experience of the Spanish Germ-Cell Cancer Group (GG) Eur Urol 2002; 42(6): 553-63.

24. Khan MJ, Bedi N, Naim M, Rahimi C, Kalsi J. Testis sparing surgery for small testicular masses and frozen section assessment. Cent European J Urol 2018; 71(3): 304-09.

25. Paffenholz P, Held L, Loosen SH, Pfister D, Heidenreich A. Testis sparing surgery for benign testicular masses: diagnostics and therapeutic approaches. J Urol 2018; 200(2): 353-60. 